\title{
Liberation and Frustration: Fifty Years after Brown
}

The point which we must aim at is to obtain admission for our children into the nearest school house and the best schoolhouse in our respective neighborhoods.

Frederick Douglass (1859)

Each school morning six-year-old Linda Brown left her small house and crossed a set of tracks in Topeka's bustling railroad switching yards. She carefully walked on the grassy strips between the tracks, avoiding the "enormous" trains that noisily clanged by her and waving at the railway workers. This daily journey covered about six, dangerous blocks where she caught her school bus. In September 1950, her father, Oliver Brown, attempted to enroll her in the Sumner School's third grade, the neighborhood white school where she could stroll on sidewalks along tree-lined streets, only seven blocks from her house. That school's principal refused to admit her because of her race. ${ }^{2}$

Change and constancy both mark the fiftieth anniversary of the landmark federal Supreme Court decision, Oliver Brown, et al., v. Board of Education, Topeka, Kansas. Decades of struggle, led by such African-American luminaries as W. E. B. DuBois, a founder of the National Association for the Advancement of Colored People (NAACP), and Thurgood Marshall, known as "Mr. Civil Rights" in his role as the lead litigator for the NAACP's Legal Defense Fund, ultimately reversed de jure segregation, the odious practice of "separate but equal" instituted by the high court's 1896 decision Plessy v. Ferguson (See Photograph \#1). ${ }^{3}$

The NAACP's grand strategy, crafted during the early 1930s, methodically utilized the American judicial system to systematically disconnect the concepts of "separate" and "equal." The first step began with the erosion of the so-called principle of "equal." The earliest opportunity came with

'Douglass is quoted in Leon F. Litwack, North of Slavery: The Negro in the Free States, 1790-1860 (Chicago: University of Chicago Press, 1966), 142-43. The emphasis is mine. Also refer to Richard J. Altenbaugh, The American People and Their Education: A Social History (Englewood Cliffs, NJ: Merrill/Prentice Hall, 2003), 96.

${ }^{2}$ Richard Kluger, Simple fustice: The History of Brown v. Board of Education and Black America's Struggle for Equality (New York: Vintage Books, 1977), 407-09, provides a thorough social and legal context leading to the Brown ruling as well as detailed background of the principal actors.

${ }^{3}$ Charles J. Russo, "Brown v. Board of Education of Topeka, Kansas, 347 U.S. 483 (1954)," in Faustine C. Jones, et al., eds., Encyclopedia of African-American Education (Westport, CT: Greenwood Press, 1996), 65-68; idem., in Richard J. Altenbaugh, ed., Historical Dictionary of American Education (Westport, CT: Greenwood Press, 1999), 61-62, 296-97. Kriner Cash, "Plessy v. Ferguson, 163 U.S. 537 (1896), in Jones, et al., eds., Encyclopedia of African-American Education, 357-58. Kluger, Simple 7ustice, 272. See also Altenbaugh, The American People and Their Education, 302. 

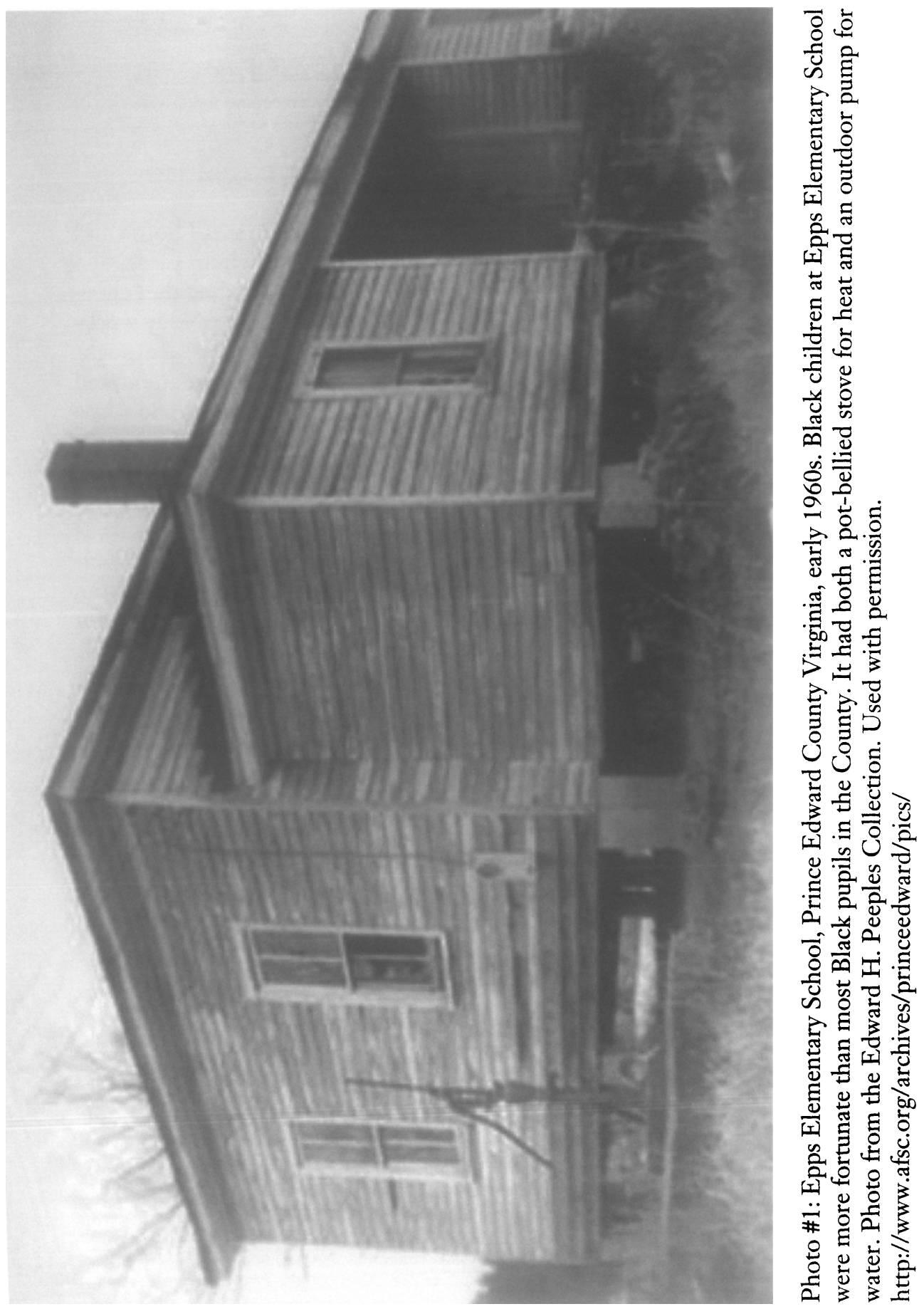
the 1938 case, Missouri ex rel Gaines v. Canada, when the federal Supreme Court ordered that the University of Missouri Law School, having failed to provide an equal facility for African Americans pursuing a legal career, accept Lloyd Gaines as a student. World War II temporary interrupted this legal campaign but it resumed in 1950 with Sweatt v. Painter. Herman Sweatt, an African-American student, had applied to the University of Texas Law School because of the inferior quality of the Texas State Law School for Negroes. When the University of Texas refused to admit him, Sweatt filed suit and the Supreme Court ruled in his favor. The final blow came that same year. After grudgingly accepting George W. McLaurin to its doctoral program, the University of Oklahoma Graduate School of Education designated a specific area for him to sit in the classroom, study in the library, and eat in the cafeteria. The Supreme Court's decision, McLaurin v. Oklaboma, ultimately put the erroneous notion of equal education, in the world of de jure segregation, to rest. ${ }^{4}$

Thurgood Marshall and the Legal Defense Fund's staff now pursued the next logical step, the eradication of "separate" education. They selected four southern states on which to build their class-action suit and based the case on evidence drawn from social science research. On Monday, May 17, 1954, the Supreme Court formally ruled that de jure segregation violated the Fourteenth Amendment to the United States Constitution. To ensure swift implementation, the Court followed a year later with Brown v. Board of Education of Topeka, Kansas, otherwise known as Brown II (See Photograph \#2). ${ }^{5}$

Once de jure segregation had been beaten, de facto segregation emerged as the next challenge. In order to integrate the public schools, a long and arduous process of school desegregation, to overcome entrenched, residential separation, unfolded. Four clear stages marked this next struggle. "Absolute defiance" by staunch, southern segregationists characterized the first phase, extending for four years after Brown II. The successful but confrontational desegregation of Central High School in Arkansas, during the 1957-58 school year, by the "Little Rock Nine," with 1,200 troops from the 101st Airborne Division dispatched to enforce federal authority, best

${ }^{4}$ Altenbaugh, The American People and Their Education, 302; Kluger, Simple fustice, 13137; John E. Fleming and Edna C. Diggs, Missouri ex rel Gaines v. Canada, 305 U.S. 337 (1938)," in Jones, et al., eds., Encyclopedia of African-American Education, 299-300; Johnny Edward Brown and William C. Akins, "Sweatt v.Painter, 339 U.S. 629 (1950)," in Jones, et al., eds., Encyclopedia of African-American Education, 451-52; James E. Newby, "McLaurin v. Oklaboma State Regents for Higher Education, et al., 339 U.S. 637 (1950)," in Jones, et al., eds., Encyclopedia of African-American Education, 284-85.

'Kluger, Simple fustice, 450; Charles J. Russo, "Brown v. Board of Education," 65-68; J. Harvie Wilkinson, III, From Brown to Bakke: The Supreme Court and School Integration, 19541978 (Oxford: Oxford University Press, 1979), $28,32$. 


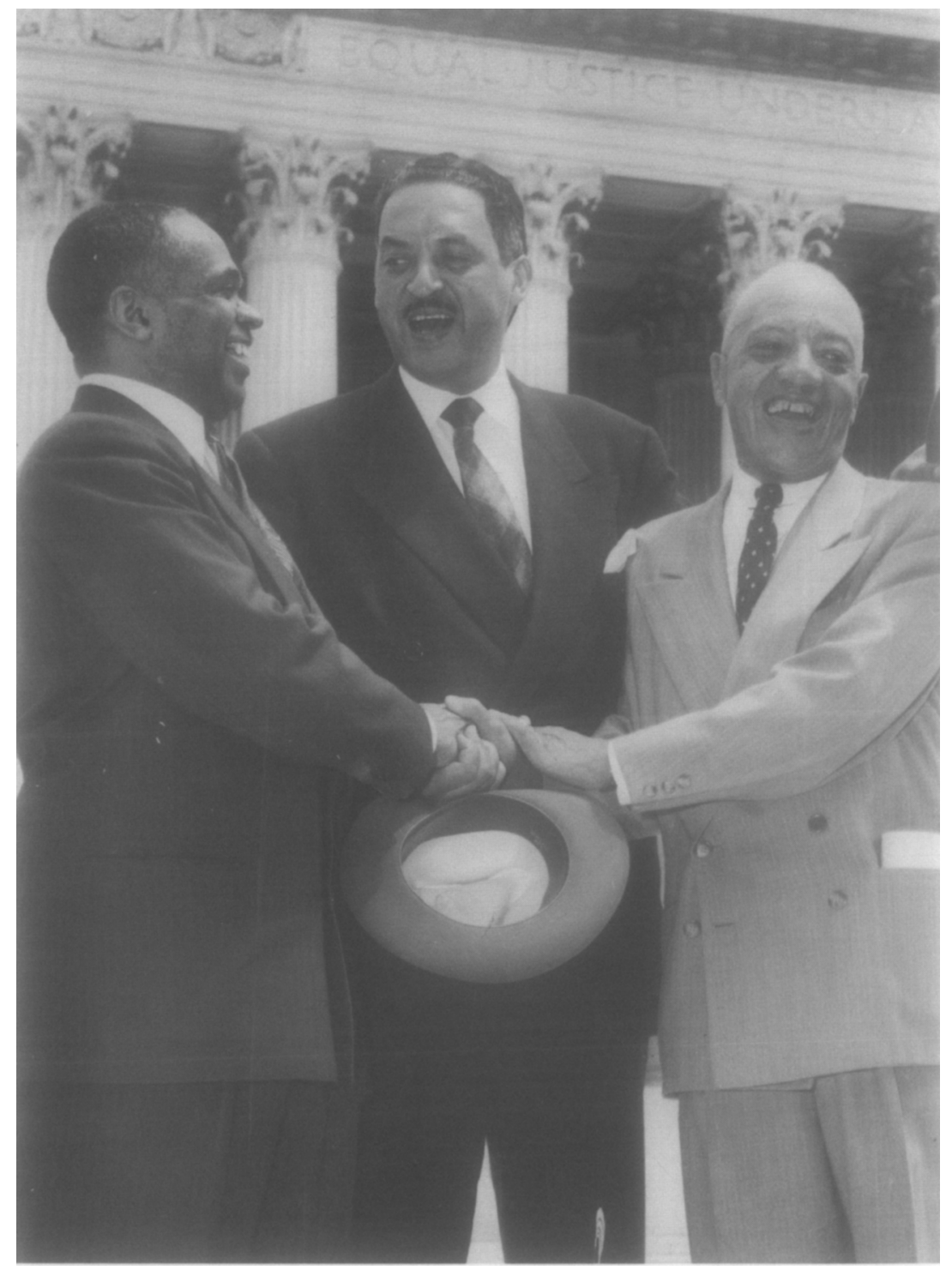

Photo \#2: George E.C. Hayes, Thurgood Marshall, and James Nabrit congratulating each other, following Supreme Court decision declaring Segregation unconstitutional, 1954. Library of Congress, Prints and Photographs Division, LC-USZ62-111236. 
illustrates the extent of this extremism (See Photograph \#3). The second period, known as "token compliance," occurred between 1959 and 1964. It involved superficial compliance by utilizing "white pupil-placement boards" to select a few African-American children for acceptance into white schools. This not only ignored the majority of African-American students, but isolated those few in largely hostile environments. With the courts largely thwarted, "modest integration" began in earnest with the 1964 Civil Rights Act. For the next several years the activism and oversight provided by the legislative and executive branches forced limited compliance in southern rural as well as urban schools. Some progress occurred but not enough: desegregation remained nominal in the South and virtually untouched in the North. ${ }^{6}$

Both school busing to overcome de facto segregation and a national focus marked "massive integration." This fourth stage, occupying the 1970s and much of the 1980s, began to unfold in 1971 when the federal Supreme Court ordered busing, in Swann v. Charlotte-Mecklenburg, to facilitate the desegregation of the public schools in Charlotte, North Carolina. The Supreme Court ultimately applied the same principle to northern public schools, mandating busing in its 1972 ruling, Keyes v. [Denver] School District. ${ }^{7}$ However, the practice of de facto segregation proved to be intractable in the urban North, and government-ordered busing led to the tragic 1974 Boston school desegregation riots that pitted African-American children against hostile, white working-class South Boston. ${ }^{8}$

Republican presidential candidate Richard M. Nixon, during the 1968 presidential election, successfully courted white southern voters by opposing civil rights. His subsequent conservative Supreme Court appointments led to the 1974 decision, Milliken $v$. Bradley, which severely circumscribed the use of busing to desegregate the public schools. That ruling prohibited buses from crossing school district lines. With interdistrict busing forbidden, only intradistrict desegregation could occur; complete integration,

${ }^{6}$ Wilkinson, From Brown to Bakke, 78, 86, 103, 105-06, 108, provides superb periodization for this phenomenon. See as well Altenbaugh, The American People and Their Education, 306. Melba Pattillo Beals offers a personal perspective of the Little Rock Nine in Warriors Don't Cry: A Memoir of the Battle to Integrate Little Rock's Central High (New York: Washington Square Books, 1994).

'Wilkinson, From Brown to Bakke, 55-56, 78; Lisa Williams Edwards, "Swann v. Charlotte-Mecklenberg Board of Education, 402 U.S. 1 (1971)," in Jones, et al., eds., Encyclopedia of African-American Education, 449-51; Charles J. Russo, "Swann v. Charlotte-Mecklenberg Board of Education, 402 U.S. 1 (1971)," in Altenbaugh, The Historical Dictionary of American Education, 356-57; "Derrick A. Bell, "Keyes v. School District No. 1, 413 U.S. 189 (1972)," in Jones, et al., eds., Encyclopedia of African-American Education, 244-46.

${ }^{8}$ See Ronald P. Formisano's analysis, Boston Against Busing: Race, Class, and Etbnicity in the 1960s and 1970s (Chapel Hill: University of North Carolina Press, 1991). 


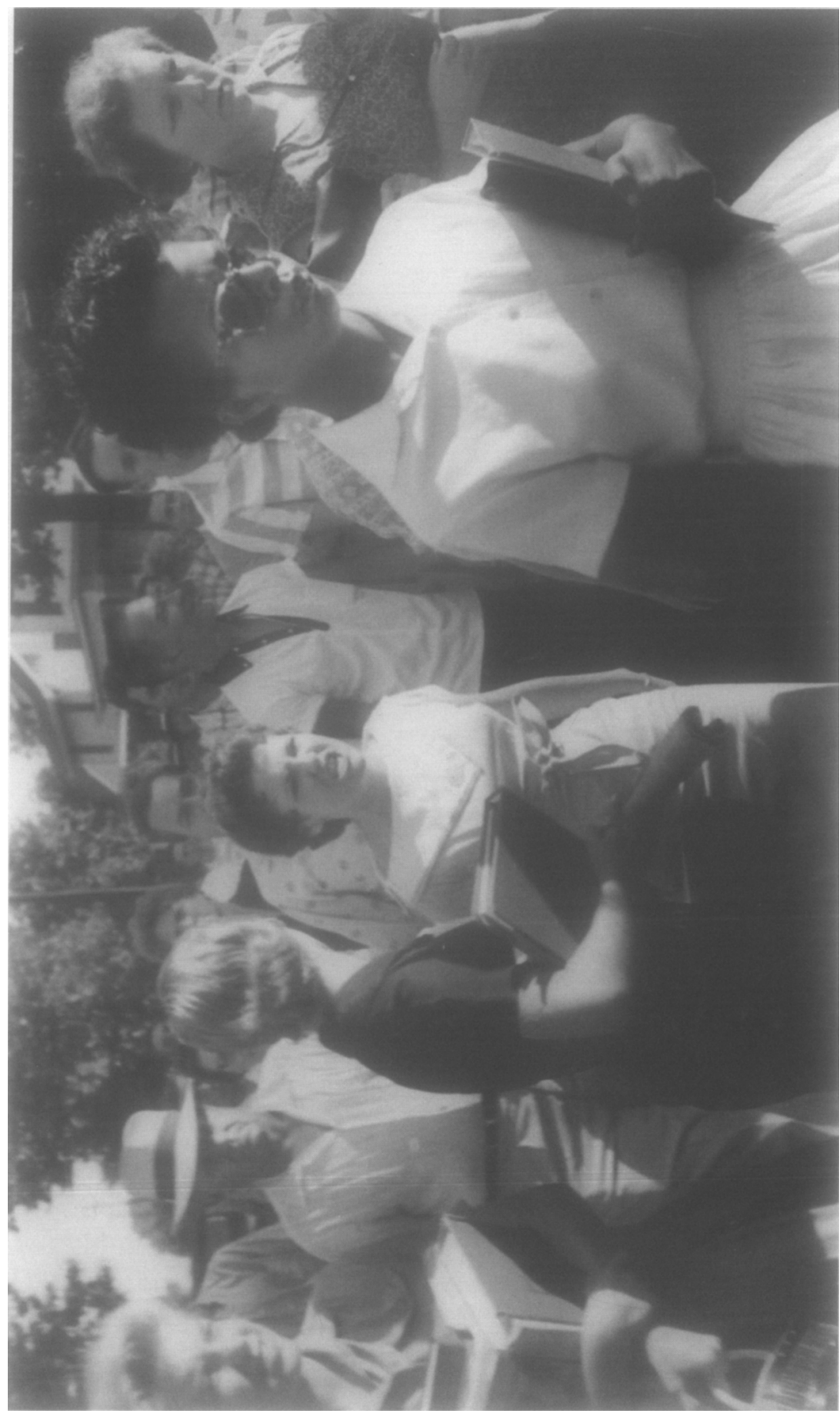

$\stackrel{8}{\circ}$

¿

$\infty$

岂

몬

$\nabla$

y

0

ปี

○

تี

$\frac{\pi}{n}$

过

$\pi$

응

ह

so

焉

.

동. ำำ

需

동

융

อี ํำ

을

龹

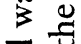

문

온

I

吉氙

ก

กี

四

$\ddot{\sim} \mathrm{O}$

\#

욜

定 
therefore, remained elusive. Marshall, dissenting as a Justice on the Supreme Court, called this a "giant step backward" from the Brown decision."

The long resegregation process began in the 1980s. President Ronald Reagan's administration opposed desegregation, falsely portraying it as an abject failure as well as an imposition on whites, and enacted numerous policies that ensured that it would not succeed. It cut federal funds that enforced desegregation, reduced the number of Desegregation Assistance Centers by 75 percent, refused to file any desegregation suits, eliminated federally funded desegregation research, endorsed the dismantling of school busing in Norfolk, Virginia, and supported the notion of neighborhood schools. This trend continued in President George Bush's administration. With conservative Supreme Court Justices in place, many school districts returned to segregated status with the full backing of the law. As we move into a new century, American society is closer to Plessy than we were fifty years ago. ${ }^{10}$

This commemorative issue attempts to analyze the impact of the Brown decision within a broad array of everyday experiences in American education at all levels through scholarly pieces as well a teaching forum, a retrospective, and essay as well as book reviews. Traditional treatments of Brown have tended to fixate on students' experiences in the post-de jure segregation era, with the generally unchallenged assumption persisting that, in spite of white resistance, this landmark decision largely benefited African Americans. Michael Fultz's opening essay, "The Displacement of Black Educators Post-Brown: An Overview and Analysis," redirects our attention to a problematic and unintended outcome of integration, that of AfricanAmerican teachers who lost their jobs in the wake of desegregation. Jonathan Zimmerman, in "Brown-ing the American Textbook: History, Psychology, and the Origins of Modern Multiculturalism," introduces us to the cultural impact of the Brown decision at the classroom level. He analyzes the changes in school knowledge at that level, delivered through standardized textbooks. In addition to the costly human toll and the profound cultural shift, Marybeth Gassman, in "Rhetoric vs. Reality: The Fundraising Messages of the United Negro College Fund in the Immediate Aftermath of the Brown Decision," reveals the philosophical debates that Brown engendered. She, in particular, examines the fundamental influence of desegregation at traditional African-American colleges in general and on the

${ }^{9}$ Gary Orfield, Susan E. Eaton, et al., Dismantling Desegregation: The Quiet Reversal of Brown v. Board of Education (New York: New Press, 1996), 9, 10-13; Marshall is quoted on p. 29. Refer as well to Charles J. Russo, "Milliken v. Bradley, 418 U.S. 717 (1974)," in Jones, et al., eds., Encyclopedia of African-American Education, 293-94; idem., "Milliken v. Bradley, 418 U.S. 717 (1974)," in Altenbaugh, Historical Dictionary, 293-94.

${ }^{10}$ Wilkinson, From Brown to Bakke, 78, mentions a fifth stage in the desegregation experience, i.e., resegregation. Orfield, et al., Dismantling Desegregation, 16-22, 27, thoroughly analyzes the entire resegregation process. 
fundraising policies of the United Negro College Fund in particular. Such scholarly investigations confront orthodoxy and reveal the social and political complexities of desegregation.

The Brown decision also presents a significant instructional challenge to our field. Preconceived and unquestioned notions, such as the integration of the American public schools, on the part of our students, must be met head-on in light of more recent developments, such as the virtual elimination of busing and the erosion of affirmative action. Jack Dougherty, Cally Waite, Daniel Perlstein, Joy Williamson, Bernadette Anand, Michelle Fine, Tiffany Perkins, David Surrey, and Tracey Weis wrestle with the obstacles they have encountered in their classrooms, describe their teaching approaches, and provide resources.

Finally, in our quest to learn more about the impact of the Brown decision and its context, we need to revisit standard, scholarly works. In our retrospective on Richard Kluger's classic Simple fustice: The History of Brown v. Board of Education and Black America's Struggle for Equality, Robert Lowe, Wayne J. Urban, and Gilbert Gonzalez critique how this twenty-sevenyear-old study has withstood the test of time. James D. Anderson tackles two more recent and important works in James T. Patterson, Brown v. Board of Education: A Civil Rights Milestone and Its Troubled Legacy, and Jack M. Balkin, What Brown v. Board of Education Should Have Said: The Nation's Top Legal Experts Rewrite America's Landmark Civil Rights Decision. We close this issue with a series of book reviews relating to African-American history in general and desegregation in particular.

Dedicated issues, because of their specialized foci, consume a great deal of time and effort on the part of many individuals. Michael Fultz has graciously and diligently served as guest editor on this thematic contribution and, along with this journal's other associate editors, assessed submissions, shaped its structure, and guided it in the final stages. Authors and reviewers proved to be diligent, punctual, and professional with their contributions. We hope this special issue of the Quarterly exhibits the need for our continued pursuit of equality. It also celebrates the unique role of the historical perspective in shaping our reality. As the Brown ruling demonstrated, change results from struggle, whether social, political, or legal. And the Brown decision will only grow more meaningful as American society grows increasingly diverse. With current demographic trends, no numerical majority will exist in the United States by the middle of this century. ${ }^{11}$ Unfortunately, at this point in time, school integration still remains an elusive dream, one that we must tirelessly pursue. Frederick Douglass's

"Sam Roberts analysis of the 1990 census in, Who We Are: A Portrait of America Based on the Latest U. S. Census (New York: Times Books, 1993), uncovered this profound, demographic trend. Subsequent U.S. Census data have corroborated this pattern. 
words, uttered in 1872 , continue to haunt us to this day: African-American and white children "will learn to know each other better, and be better able to co-operate for mutual benefit." 12

Richard J. Altenbaugh

Editor, History of Education Quarterly

${ }^{12}$ Douglass is quoted in Altenbaugh, The American People and Their Education, 160. 